\title{
Student`s Mental Revolution Model At Senior High School
}

\author{
Sufyarma Marsidin ${ }^{1)}$, Tia Ayu Ningrum ${ }^{2)}, \operatorname{Irsyad}^{3)}$, Anisah $^{4)}$ \\ Educational Administration, Universitas Negeri Padang, Padang, Indonesia \\ E-mail: sufyarma1945@gmail.com
}

Educational Administration, Universitas Negeri Padang, Indonesia

E-mail: tia.ayu.ningrum92@gmail.com

\begin{abstract}
The background of this research was the existence of mental or the character of problems the current learner. The purpose of this research was (1) to know about the guidance of integrity, work ethic, mutual cooperation, independence, religious at senior high school level, (2) prototype model of Student mental revolution guidance in senior high school. This was a research development using qualitative approach. The results of this study explain that (1) guidance of mental revolution values (integrity, mutual cooperation, work ethic, self-reliance and religious) has not been implemented maximally in senior high school. The process of guidance was done on intracurricular and extracurricular activities. Guidance of mental revolution on intracurricular activities did independently and integrated on subjects. (2) This research also produced prototype model design of students guidance. This model illustrates all internal stakeholders and school supervisors that play a role in the process of guidance students. The guidance was done by using the approach of exemplary, habituation, praise and reward that emphasizes aspects by knowing, by loving, by acting, and done individually and in groups. Guidance was done on extracurricular and intracurricular activities that give consideration the values of Pancasila, UUD 1945, Bhineka tunggal ika, and NKRI regulations.
\end{abstract}

Keywords: Guidance, Mental revolution, Students 


\section{INTRODUCTION}

Indonesia is facing a moral and moral crisis currently. This can be seen from the various phenomena that occur in the social life of the community. The existing phenomenon is not in accordance with the purpose of the nation and state. It produce a good morals and mental of people. As constitution No. 20 of 2003 that is to develop the potential of student to be a human being who believes and cautious to God Almighty, good mental/character, healthy, knowledgeable, capable, creative, independent, and become citizens of a democratic and responsible .

But hope does not match the existing phenomena that there are negative behaviors arising from various backgrounds ranging from the public, students, and others indicate that the character owned still very less even more inclined today do not have the appropriate character in the norms of society. For that researchers do observations at schools in the Foundation PGAI Padang one of its mission to produce students who have good character/mental but there are phenomena:

There are still students who do the brawl of students, causing damage to the environment of the occurrence of brawl and injured students who do brawl.

There are still students who hang around during school hours in the school environment and outside the school environment. There are still students who come late to school and go to class when the lesson has started. There are still students who fight with other participants in school.

There are still students who talking harshly. The above phenomena describe morals and mental is still not good. Therefore, character and mental guidance is so need to give contribute in problems solving of the mental and character crisis today. This is because mental and character education is a deliberate effort to help and understand people and care about the values of ethical / moral, (Gunawan, 2012). And character education has become an educational movement that supports emotional development, by both schools and governments to help students develop the core of ethical values and performance values, such as caring, honesty, crafts, tenacity and fortitude, responsibility, self-respect and others (Samani and Hariyanto, 2012).

Guidance of the mental and character values can be done optimally with integrated in subjects (religion), (Azizah, 2015). Marzuki (2015) also said that mental and character guidance can be done with extracurricular activities (Scouts). For that it need to know how the guidance of mental revolution in student.

So based on that, the purpose in the research were (1) How to guidance integrity, work ethic, mutual cooperation, independence, relegius at senior high school in Dr. $\mathrm{H}$. Abdullah Ahmad PGAI Padang foundation? (2) How to prototype model student mental revolution In senior high school?.

\section{METHODS}

This research was research development (Research and Development) by using qualitative approach. The development research that has been done using Borg and Gall model (1989: 775) has five steps by combining several development study cycles. Researchers taked several steps of development research and then combine it with the design concept of ADDIE development (analysis, design, development, implementation, evaluation). However, in this study only came to the design of guidance model of mental revolution of learners.

Techniques and data collection tools were done by interview, observation and documentation. Then techniques of data analysis in accordance with his opinion Bogdan and Biklen (1982: 189) which said that analysis includes activities to do data, data reasoning, divide it into units that can be managed, synthesize it, find patterns, find important thing and what will be learned and decided what will be reported". There were three steps in data analysis according to Miles and Huberman (1984: 21), he believes data reduction, data presentation, conclusion / verification. Research guidance of students' mental revolution done in senior high school in the Dr. H. Abdullah Ahmad PGAI Padang Foundation.

\section{RESULT AND DISCUSSION}

\section{Development of Mental Revolution Values at Senior High School Level.}

The values of the mental revolution was fostered in senior high school Dr. H Abdullah Ahmad PGAI Padang were integrity, work ethic, mutual cooperation, independence and relegius. Based on the results of the study of mental values revolution (integrity, work ethic, mutual cooperation, independence, relegius) at the level of senior high school has not been implemented maximally. It was because not all the values in the mental revolution has been guided on senior high school Dr. $\mathrm{H}$ Abdullah Ahmad PGAI Padang foundation.

Based on the results of research was known that the value of integrity being fostered in senior high school was the value of honesty, trustworthy and responsibility. The value of work ethic developed in senior high school were competitiveness, innovative, creative and optimistic. While the value of work ethic that has not implemented its guide was productive. The value of mutual cooperation that was fostered in senior high school was the value of cooperation, solidarity, communal and oriented to the community. Religious values that was fostered in senior high school were the value of faith, islam, ihsan, science and charity. And the form of the value of the independence that was fostered in the senior high school were the value of social independence, intellectual, and emotional. The guidance of mental revolution in senior high school was carried out in intracurricular and extracurricular activities. The guidance of revolutionary values on intracurricular activities was done directly that there was related material in the subject and done integrated in the learning process.

Based on the results of research at senior high school Dr. H. Abdullah Ahmad PGAI Padang. It was known that the form of mentoring mental revolution in integrity aspect can be seen from intracuricular and extracurricular activities. Character building in intracuriculer seen in the learning process. The values of the characters planted here were honest, believable, and responsible.

The form of guidance work ethos to the student in the learning process was to teach the student has the competitiveness to do his job, learned the student to be optimistic about the task he made, learned student can bring up new ideas in learning, learned student to have skills.

The form of value mutual cooperation fostered in senior high school was guided the value of cooperation, solidarity, 
communal and oriented to the benefit. The value of mutual assistance formulated in senior high school were the value of faith, Islam, ihsan, science and charity. And the form of value of independence that fostered in high school were the value of emotional independence, intellectual independence, economic independence and social independence

Based on the results of the research was known the character and mental condition of student was not good. It was influenced by the use values that not all mental revolution was implemented on supporting them. Based on this, it was necessary to analyze that it was necessary to apply all values to all educational units in order to produce good mental and character student in all educational units. The effort of each educational unit in shaping good mental and character of student can be done by implementing government policies on mental revolution program. The program of mental revolution comes from the coordinating ministry and the field of human development and culture of the Indonesian republic.

The mental revolution program need to be implemented. Schools need to guide five character values or mental revolution in government policy so it is expected to produce student who has good character or mentality.

\section{Model Protipe Mental Revolution Development of Learners}

Prototype model was produced in this study was a prototype model of guidance mental revolution of students. In this research, done needs analysis of student mental revolution and model design of student mental revolution guidance.

\section{Needs Analysis Model Development Mental Revolution \\ Educative Participants}

Based on this research, it was known that many student in Indonesia who bermental less good. Besides looking at the phenomenon that existed in Senior high school in Dr.H. Abdullah Ahmad PGAI Padang foundation, the related data is also support the need for needs analysis for the development of mental revolution of learners. Data such as: 3,8-4.2 million drug users in Indonesia among students and students (BNN, 2012), 64\% of students and students of university see pornography so that $39 \%$ of respondents from the age of 15-19 years and 25\% of age 2025 years have been having sex outside of marriage (KPAI, 2016), free sex, 800 types of original pornographic video of domestic production, $90 \%$ of the video played by students and students of university (KPAI, 2016), Abortion Case, almost 2,4 million occur annually, and the perpetrators are adolescents (Komnas HAM 2016), Prostitution, 150,000 children under the age of 18 years become sex workers, half of the sex workers are under. the age of 18 year, while 50,000 of them have not reached the age of 16 years (KPAI, 2016), Brawl of students and students of university, in 2012 there have been 139 brawl of brawl case, even 12 cases cause death, and in 2011 from 339 cases of brawl causing 82 children died (KPA1, 2016 ), Motorcycle gangs, gambling betting gangs ranging from 5 to 25 million rupiahs per one wild race, resulting in about 60 men every year (KPAI, 2016). Phenomena it describes the condition of the character and mental of the learner not good.

\section{Design Model of Mental Revolution of Student}

At this research, researcher designed a model of mental revolution for students in senior high school. The model was designed based on an assessment instrument using a variable integrity, work ethic, mutual cooperation. This variable refers to the government's policy on mental revolution add considering independence and relegius value. The five variables was done guidance in intracurriculer and extracurricular activities. They are

\section{Development of Mental Revolution Values of Learners On School Intracurricular}

One way in fostering the values of the mental revolution is by fostering the values of mental revolution in the intracurricular activities of the school. This guidance can be done in two ways, they are independent on some subjects (KWN, Religion and BK) and being integrated in a wide range of subjects. Guidance of student mental revolution with independent approach is done in a way, on some subjects there is material on the values of mental revolution on the subjects in schools. While integration means carried out the cultivation of the values of mental revolution in students and the learning process. Guided students and shaped to have a mental revolution values so that produce good students.

The guidance of mental revolution which is done in intracurriculer activity which is implanted to the learners based on the values of Pancasila, the Constitution, UU No. 20 of 2003 and Pepres no 87 of 2017. Each character values formation should be attention the policies and applicable laws so that the attitudes and mental of the students do not conflict with the prevailing policies.

\section{Guidance Values Mental Revolution At School Extracurricular}

The second way in fostering the values of mental revolution is by fostering the values of mental revolution in the school's extracurricular. This guidance can be done by integrating the values of mental revolution in the extracurricular activities that are in school. Extracurricular activities that exist in the educational unit of the activities of relegius, sports, art and scout for senior high school.

Each type of extracurricular activity is done by producing the values of mental revolution (integrity, work ethic, mutual cooperation, independence and relegius). So, in the implementation of extracurricular activities is not only made student hasthe skills but also educate and shape the attitude and mental students.

The guidance of mental revolution in extracurricular activities to student is based on the values of Pancasila, the constitution, UU no. 20 of 2003 and Pepres no. 87 of 2017. Each character value formation should take into account the prevailing policies and laws so that attitudes and the student's mental does not conflict with the prevailing policies.

Thist is the design of students model revolution guidance in senior high school:

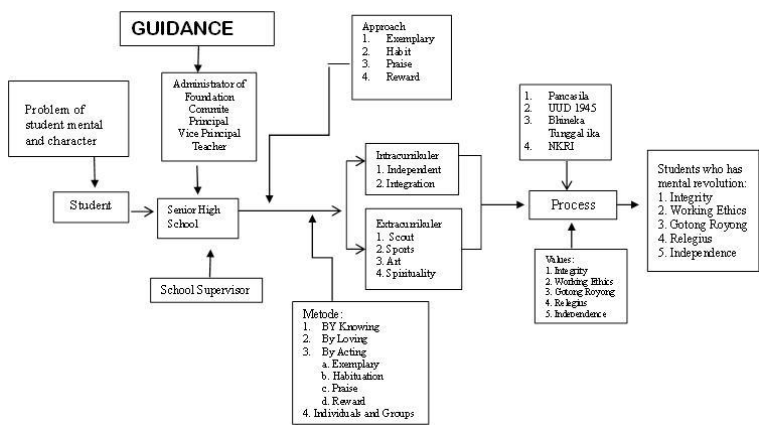

Figure 1 Prototype Model of Students Model Revolution Guidance in Senior High School 
This model illustrates that all internal stakeholders and school supervisors play a role in the process of fostering students. The guidance is done by using the approach of exemplary, habituation, praise and reward that emphasizes aspects by knowing, by loving, by acting, and done individually and in groups. Guidance is done in extracurricular activities and intracurricular who consider the values of Pancasila, UUD 1945, bhineka tunggal ika, and regulations NKRI.

Based on the results of the research that the mental condition of most student was not good. This was caused by the using values has not been implemented mental revolution as a whole. Based on this, it was necessary to do an analysis of the application of use values of all the educational unit to produce student that good mentality and good character / moral in all educational units. Good Mental and good character/morals was the ideals of the Indonesian people on UUD 1945. Character Indonesian is a nation character. Conversely, a nation does not have a character is a nation that does not have a moral and mentak or has a standard of norms and good behavior (Arifin, 2012: 20). That's why character education is important because character education produce students into positive personality and good morals in accordance with the competency standards graduates (SKL) so that it can be implemented in life everyday ( Fitri, 2012:22).

The need education is accordance with the expected society, nation and state. It is to be a man of faith and cautious to God almighty, morally good, healthy, knowledgeable, capable, creative, independent, and become a democratic citizen and responsible (UU No. 20/2003).

The importance of mental and character guidance demande each unit of education in shaping the good mental and character of student can be done by implementing government policies on mental revolution program. The program of mental revolution comes from the Coordinating Ministry and the field of human development and culture of the Indonesian republic.

According to the Coordinating Ministry for Human Development and Culture (2015) the mental revolution is an entire movement society (government \& people) in a way quickly to take back the values strategic which is needed by the Nation to be able create order and people welfare so as to win the competition in globalization. Mental change the way view, mind, attitude, behavior-oriented and progress modernity. So that Indonesia becomes a great nation and able to compete with nations - other nations world. The mental revolution changed the outlook, thoughts, attitudes, progress-oriented behavior and modernity, so that Indonesia became a nation is able to compete with the nation else in the world.

The Coordinating Ministry for Human Development and Culture of Indonesia, values in the policy of the mental revolution are as follows:

a. Integrity: values that describe integrity are honest, trustworthy, character and responsibility.

b. Work ethic: values that describe work ethic are competitiveness, optimism, innovative and productive mutual

c. cooperation: the values that describe gotong royong are cooperation, solidarity, communal, oriented towards the benefit.

Guidance of mental revolution is needed to be implemented by the school. That is because the character education and guidance of the mental revolution is something that done teachers. It is able to influence the character students. Teachers help shape the character of students. This is includes exemplary the behavior of teachers, how the teacher spoke or convey, tolerant teacher, and various things other related ( Gunawan, 2012).

The model is designed with Marzuki (2015) and (Azizah, 2015) that guidance of mental and character values can be done optimally with integrated in subjects (religion) and can be done with extracurricular activities (Scouts). But in the design of this model not only focus on religious subjects but also other subjects. And not only focus on scouts alone but also sports, arts and religion.

This design is also adjusted with the opinion Sudjana, (2000: on the concept guidance profersional control of all the elements organization so that elements could be function as appropriate so that the plan to achieve the goal can be implemented efficiently and effectively. And also the opinion of Thoha (2004) says that guidance is an action, process, result, or statement better. In this case it shows the progress, growth improvement, evolution over the possibilities, developing or enhancement of something.

Guidance of student's mental is important to get better results. The guidance of student's mental is also important to : (1) Developing potential of heart/conscience /affective student as human and citizens who have values culture and character of the nation; (2) Developing habits and behavior of praised student and in line with universal values and religious nation culture traditions; (3) Planting leadership and responsibility of the participant educated as generation of the nation's successor; (4) It represents the ability of learners to be an independent, categorical, and nationalized human being: (5) Developing the school life environment as a safe, honest, ful of creativity and friendship, and with a strong sense of nationality and power: (6) Correct student's inconsistent behavior with the values developed by the school; (7) Establish harmonious connections with family and community in playing the role of the education of character together.

Then, the development of values in every education unit should be based on Pancasila, UUD 1945, UU No. 20 of 2003 and Presidential Decree No. 87 of 2017. This is because Pancasila, UUD 1945, UU No. 20 of 2003 and Presidential Regulation No. 87 of 2017 is an educational or juridical educational foundation. The juridical or education law means a set of applicable legislation which is the starting point or reference (material, and conceptual) in the context of educational practices and educational studies.

In addition to being based on the juridical foundation, the guidance of the mental revolution must also be adapted to the social and cultural foundations. The culture in question is the minang values and cultural. This is because the development of model design and implementation is carried out at Dr. H. Abdullah Ahmad PGAI Padang

\section{CONCLUSIONS}

The research explained about (1) guidance of mental revolution values (integrity, mutual cooperation, work ethic, independent and relegius) have not been implemented to the maximum in the education unit senior high school. The process of guidance is done on intracurricular and extracurricular activities. Guidance of mental revolution on 
intracurricular activities done independently and integrated on subjects. (2) The research also produced a prototype model design guidance learners. This model illustrates that all internal stakeholders and school supervisors play a role in the process of fostering student. The guidance was done by using the approach of exemplary, habituation, praise and reward that emphasizes aspects by knowing, by loving, by acting, and done individually and in groups. The guidance was done in extracurricular and intracurricular activities that consider the values of Pancasila, UUD 1945, Bhineka Tunggal Ika, and NKRI regulations

\section{REFERENCES}

Arifin, M. Dan Barnawi. 2012. Strategi dan Kebijakan Pembelajaran

Fitri, Agus Zaenul.2012. Pendidikan Karakter Berbasis Nilai Dan Etika Di Sekolah. Yogjakarta: Ar- Ruzz Media.

Gunawan, Heri. 2012. Pendidikan Karakter

Konsep dan Implementasi. Bandung: Alfabeta.Sukirman,dkk. (2009). Administrasi dan Supervisi Pendidikan. Yogyakarta: UNYPress

Marzuki dan Lysa Hapsari. 2015. Pembentukan Karakter Siswa Melalui Kegiatan Kepramukaan dI MAN 1 Yogyakarta. Jurnal Pendidikan karakter Volume 5, Nomor 2.

Miles M.B. and Huberman. 1984. Complementary Methods for Research ini Education Change.Washington: ARA.

Republik Indonesia. 2003. Undang-Undang No. 20 Tahun 2003 tentang Sistim Pendidikan Nasional. Sekretariat Negara. Jakarta.

Republik Indonesia. 2015. Kementerian Koordinator Bidang Pembangunan Manusia dan Kebudayaan. Tentang Program Revolusi Mental tahun 2015. Sekretariat Kabine RI.

Jakarta.

Samani dan Hariyanto.2012. Pendidikan

Karakter, Konsep dan Model, Bandung: Remaja Rosdakarya.

Sudjana, Nana. 2000. Dasar-Dasar Proses Belajar Mengajar. Bandung. PT. Sinar Baru Algesendo.

Thoha, Mifta. 2004. Kepemimpinan dalam Manajemen. Jakarta: PT Grafindo Persada.
Azizah, Nur. 2015. "Penanaman Nilai-Nilai dalam Pembelajaran Pendidikan Agama Islam di SMA Negeri 1 Weleri Kendal”. Skripsi. Universitas Islam Walisongo.

Bogdan, R.C dan Biklen, S.K. 1982. Qualitative Research for Education : An Introduction to Theory and Mehtods, Boston : Allyn and Bacon, Inc.

Borg, W.R. dan Gall, M.D 1989. Educational Research An Introduction. New York 
